Vol 1. No 1. Juli 2021 e-ISSN : 2798-5733 P-ISSN : 2798-5741

\title{
UPAYA PENINGKATAN PRESTASI BELAJAR AQIDAH AKHLAK MELALUI METODE COOPERATIVE SCRIPT UNTUK SISWA MTSN 1 BAUBAU
}

\author{
ZAMRIA \\ MTs Negeri 1 Baubau Provinsi Sulawesi Tenggara \\ Email : zamrianur2009@gmail.com
}

\begin{abstract}
ABSTRAK
Penelitian ini bertujuan untuk mengetahui upaya peningkatan prestasi belajar Aqidah Akhlak melalui metode Cooperative Script untuk siswa kelas VIII MTs Negeri 1 Kabupaten Baubau Provinsi Sulawesi Tenggara semester genap tahun pelajaran 2019/2020. Metode yang digunakan dalam penelitian ini adalah metode penelitian tindakan kelas (PTK). Sedangkan teknik pengumpulan data yang digunakan adalah observasi, tes, wawancara, dokumentasi dan data dianalisis secara deskriptif. Penelitian ini dilakukan dalam 3 siklus yakni siklus I siklus II dan siklus III. Subjek penelitian adalah 26 orang siswa kelas VIII 1 MTs Negeri Baubau tahun pelajaran 2019/2020. Setelah dilakukan penelitian di kelas VIII 1 MTs Negeri Baubau, hasil belajar siswa dengan menggunakan metode pembelajaran Cooperative Script mengalami peningkatan, yaitu pra siklus rata- rata 72,8 dengan ketuntasan 44\%, siklus I rata-rata 81,6 dengan ketuntasan $72 \%$, siklus II rata-rata 96 dengan ketuntasan 96\%, dan siklus III rata-rata 96,8 dengan ketuntasan $100 \%$. Dengan demikian, metode pembelajaran Cooperative Script dapat meningkatkan hasil belajar siswa kelas VIII 1 MTs Negeri Baubau semester genap tahun pelajaran 2019/2020.
\end{abstract}

Kata Kunci: prestasi belajar, aqidah akhlak, cooperative script.

\section{PENDAHULUAN}

Dalam meningkatkan kualitas pendidikan, guru merupakan komponen yang sangat penting, sebab keberhasilan pelaksanaan proses pendidikan sangat tergantung pada guru sebagai ujung tombak. Kualitas pendidikan sangat bergantung pada kualitas pembelajaran. Dewasa ini, telah terjadi pergeseran pola sistem mengajar yaitu dari guru yang mendominasi kelas menjadi guru sebagai fasilitator dalam proses pembelajaran. Dalam rangka meningkatkan kualitas pembelajaran guru harus mampu menciptakan kondisi belajar yang aktif dan kreatif. Belajar adalah kegiatan yang berproses dan merupakan unsur yang sangat fundamental dalam penyelenggaraan setiap jenis dan jenjang pendidikan. Ini berarti, berhasil atau gagalnya pencapaian tujuan pendidikan itu amat bergantung pada proses belajar yang dialami siswa baik ketika ia berada di sekolah maupun di lingkungan rumah atau keluarganya sendiri (Syah, 2013: 63).

Pembelajaran adalah proses interaksi siswa dengan guru dan sumber belajar pada suatu lingkungan belajar. Standar Proses Pendidikan adalah standar nasional pendidikan yang berkaitan dengan pelaksanaan pembelajaran pada satu satuan pendidikan untuk mencapai standar kompetensi lulusan (Zamil, 2017). Peningkatan kualitas pendidikan dilaksanakan di antaranya dalam bentuk pengembangan metode penyampaian materi pembelajaran, pengembangan kurikulum, serta pengembangan berbaga jenis metode pembelajaran. Salah satu bagian integral dari upaya pembaharuan berupa inovasi metode pembelajaran. Tumbuhnya kesadaran terhadap pentingnya pengembangan metode pembelajaran di masa yang akan datang harus dapat direalisasikan dalam bentuk nyata. Jenis metode pembelajaran yang digunakan oleh guru sangat mempengaruhi motivasi, minat, sekaligus hasil belajar siswa (Widyawati, dkk, 2015).

Setelah melalui proses belajar maka Siswa diharapkan dapat mencapai tujuan belajar yang disebut juga sebagai prestasi belajar dalam bentuk hasil belajar yaitu kemampuan yang dimiliki Siswa setelah menjalani proses belajar. Sudjana berpendapat, hasil belajar adalah kemampuan-kemampuan yang dimiliki Siswa setelah ia menerima pengalaman belajarnya 
(Sudjana, 2004: 17). Tujuan belajar adalah sejumlah hasil belajar yang menunjukan bahwa Siswa telah melakukan perbuatan belajar, yang umumnya meliputi pengetahuan, keterampilan dan sikap-sikap yang baru, yang diharapkan dapat dicapai oleh Siswa (Jihad \& Haris, 2013: $15)$.

Siswa SMP berusia sekitar 11-15 tahun. Peaget (Slavin, 2011:.45-55) menyatakan bahwa pencapaian utama dalam usia ini berupa pemikiran abstrak dan semata-mata simbolik juga dimungkinkan. Karakteristik siswa SMP yang menyukai gambar atau simbol mengindikasikan bahwa secara alamiah siswa menyukai imajinasi yang lebih luas untuk memahami. Siswa SMP berada pada masa peralihan dari anak-anak ke masa remaja. Oleh karena itusiswa SMP paling rawan terhadap pengaruh lingkungan sekitar yang baik maupun yang kurang baik.

Dalam Aqidah akhlak, menurut Nurhayati (2014) aqidah akhlak bagi siswa berguna agar siswa diarahkan untuk mencapai keseimbangan antara kemajuan lahiriah dan batiniah, keselarasan hubungan antara manusia dalam lingkup sosial masyarakat dan lingkungannya juga hubungan manusia dengan Tuhannya. Dan dengan pendidikan Aqidah Akhlak pula siswa akan memiliki derajat yang tinggi yang melebihi makhluk lainnya. Mata pelajaran Aqidah Akhlak bertujuan untuk menumbuhkan pola tingkah laku siswa yang bulat melalui latihan kejiwaan, kecerdasan, penalaran, perasaan dan indera. Pendidikan Aqidah Akhlak dengan tujuan semacam itu harus melayani pertumbuhan siswa dalam segala aspeknya, baik aspek spiritual, intelektual, imajinasi, jasmaniah, ilmiah maupun Bahasa (Hodijah, 2016).

Mata pelajaran Aqidah Akhlak merupakan pelajaran yang diampu mulai dari tingkat Madrasah Ibtidaiyah, Tsanawiyah dan sampai tingkat Aliyah bahkan tingkat perkuliahan dan umum. Adapun pembelajaran Aqidah Akhlak bertujuan untuk menumbuhkembangkan aqidah melalui pemeberian, pemupukan, penghayatan, pengembangan pengetahuan sampai dengan pembiasaan dalam pengamalannya. Semua itu diwujudkan dengan menerapkan Aqidah dan Akhlak yang baik dan terpuji dalam kehidupan beragama dan sosial sehari-hari (Pamuji, 2018).

Di era globalisasi yang semakin maju seperti sekarang ini, banyak hal memberikan pengaruh yang positif maupun negatif bagi siswa. Jika siswa tidak pandai dalam memanfaatkan kemajuan globalisasi, maka siswa terperosok dalam praktik yang tidak baik. Hal ini dapat dilihat dari sikap dan perilaku siswa remaja dalam kehidupannya, misalnya cara berpakaian, cara bergaul, cara berbicara dan masih banyak lagi pola pikir dan pola hidup yang menunjukkan dinamisasi akibat interaksi siswa dengan produk sains dan teknologi yang semakin canggih (Muqorrobin, 2017). Oleh karena itu diperlukan metode pembelajaran yang tepat yang bisa diterapkan oleh guru agar dapat menyampaikan materi Aqidah Akhlak secara tepat dan menarik sehingga siswa semakin baik mencerna dan menerapkan materi yang diberikan.

Pelajaran Aqidah akhlak sering dianggap pelajaran yang sulit bagi para siswa, khususnya siswa yang masih remaja di MTs Negeri 1 Baubau Sulawesi Tenggara, hal ini karena kebanyakan guru dalam proses pembelajaran kurang tepat menggunakan metode, tekhnik, dan media-media yang mampu menunjang untuk membuat suasana belajar menjadi mudah dan menyenangkan bagi siswa dan yang akan mampu meningkatkan keterampilan menggunakan berbagai konsep aqidah akhlak dalam kehidupan sehari-hari siswa (Hasil pengamatan di kelas VIII 1 MTs Negeri 1 Baubau Sulawesi Tenggara, tanggal 12-14 Desember 2020). Hasil belajar Siswa pada mata pelajaran aqidah akhlak kelas kelas VIII 1 MTs Negeri 1 Baubau Sulawesi Tenggara relatif belum mampu mencapai Kriteria Ketuntasan Minimal (KKM) sebesar 75. Setelah dilakukan tes yaitu hanya 12 orang dari jumlah 26 Siswa, atau dengan rata-rata masih $44 \%$ Siswa yang sudah mampu mencapai nilai KKM dan 56\% lagi Siswa yang belum mampu mencapai nilai KKM. Merujuk pada berbagai pendapat para ahli aqidah akhlak dalam mengembangkan kreativitas dan kompetensi Siswa, maka guru hendaknya dapat menyajikan pembelajaran yang efektif dan efisien, sesuai dengan kurikulum dan pola pikir Siswa. Dalam mengajarkan aqidah akhlak, guru harus memahami bahwa 
kemampuan setiap Siswa berbeda-beda, serta tidak semua Siswa menyenangi mata pelajaran aqidah akhlak.

Untuk dapat mencapai suatu tujuan pembelajaran yakni prestasi belajar siswa, maka sebaiknya guru harus mampu menggunakan suatu metode pembelajaran. Penggunaan metode dalam pembelajaran sangat penting dalam penyampaian materi kepada siswa apalagi siswa yang masih duduk di Sekolah Dasar yang sangat memerlukan arahan dan bimbingan. Metode dalam pembelajaran mempunyai peran penting dalam penyampaian materi pada proses pembelajaran. Metode adalah salah satu alat untuk mencapai tujuan pembelajaran. Metode adalah pelicin jalan pengajaran menuju tujuan/ sasaran. Jadi, guru sebaiknya menggunakan metode yang dapat menunjang kegiatan belajar mengajar, sehingga dapat dijadikan sebagai alat yang efisien untuk mencapai tujuan (Mufarokah, 2009:80). Salah satu metode yang dapat dimanfaatkan oleh guru dalam proses pembelajaran khususnya pelajaran aqidah akhlak dapat menggunakan metode Cooperative Script.

Upaya yang dapat dilakukan untuk meningkatkan prestasi belajar Aqidah Akhlak dengan menerapkan metode kooperatif Cooperative Script. Pembelajaran dengan menggunakan model Cooperative Script guru mampu melibatkan siswa secara aktif sehingga dapat meningkatkan daya kreatif dan berfikir siswa (Shoimin, 2014: 98). Metode Pembelajaran Cooperative Script baik digunakan dalam pembelajaran untuk menumbuhkan ide-ide atau gagasan baru (dalam pemecahan suatu permasalahan), daya berfikir kritis serta mengembangkan jiwa keberanian dalam menyampaikan hal-hal baru yang diyakininya benar (Susiloyoga, 016).

Cooperative Script adalah suatu cara bekerjasama dalam membuat naskah tulisan tangan dengan berpasangan dan bergantian secara lisan dalam mengintisarikan materi-materi yang dipelajari (Dansereau, 1985). Model pembelajaran Cooperative Script ini diadaptasikan dengan kemampuan siswa dalam proses pembelajarannya serta membangun kemampuan siswa untuk membaca dan menyusun rangkuman berdasarkan materi yang dibacanya, sehingga dapat meningkatkan pemahaman konsep siswa terhadap materi yang diajarkan". (Natalina, dkk, 2013). Dengan model pembelajaran Cooperative Script, siswa akan terlatih mengembangkan ide-idenya sehingga siswa dapat mengkonstruksi sendiri penetahuan (Suryani, dkk, 2013) dan dapat membantu siswa untuk membiasakan belajar berdasarkan sumber bukan guru (Zamzani, dkk, 2013). Dengan begitu siswa tidak hanya terpaku kepada apa yang disampaikan oleh guru saja, tetapi bisa mengembangkan pengetahuan yang diterima dari sumber lain. Dalam penjelasan lain disebutkan bahwa Model pembelajaran cooperative script adalah model pembelajaran yang dalam prosesnya menuntut siswa untuk selalu aktif dalam proses pembelajaran mulai dari awal pembelajaran sampai akhir pembelajaran, sehingga dapat meminimalisir peran guru dalam kegiatan pembelajaran (Noor, dkk, 2014).

\section{METODE PENELITIAN}

Metode penelitian yang digunakan adalah metode penelitian tindakan kelas (PTK) model Kurt Lewin (Suyoto, 2016: 378). Sedangkan teknik pengumpulan data yang digunakan adalah observasi, tes, wawancara, dokumentasi dan data dianalisis secara deskriptif (Wiraatmaja, 2008: 21). Penelitian ini bertujuan untuk mengetahui upaya peningkatan prestasi belajar Aqidah Akhlak melalui metode Cooperative Script untuk siswa kelas VIII 1 MTs Negeri 1 Kabupaten Baubau Provinsi Sulawesi Tenggara semester genap tahun pelajaran 2019/2020. Penelitian Tindakan Kelas ini dilakukan di MTs Negeri 1 Kabupaten Baubau Provinsi Sulawesi Tenggara dengan subjek penelitian yakni siswa kelas VIII 1 MTs Negeri 1 Baubau berjumlah 26 orang siswa.

Penelitian ini dilakukan dengan siklus terdiri dari siklus I, siklus II dan siklus III. Karakteristik penelitian tindakan kelas adalah :1. Didasarkan atas masalah yang dihadapai guru dalam pembelajaran, 2. Dilakukan secara kolaboratif melalui kerjasam dengan pihak lain 3. Penelitis ekaligus praktisi yang melakukan refleksi, 4. Memecahkan masalah untuk 
meningkatkan mutu pembelajaran, 5. Dilakukan dalam rangkaian beberapa siklus, dan tindaknya meliputi efektivitas metode atau proses pembelajaran.

Dalam mengumpulkan data-data yang dibutuhkan peneliti melakukan beberapa kegiatan dengan menggunakan metode pengumpulan data, yaitu: (1) Metode observasi dalam penelitian adalah mengamati secara langsung dengan teliti, cermat, dan hati-hati terhadap fenomena dalam pembelajaran Bahasa Indonesia dengan menggunakan metode Cooperative Script (2) catatan lapangan yang dipakai berupa pernyataan semua peristiwa yang dialami dan didengar. (3) metode wawancara ini digunakan untuk mendapatkan gambaran permasalahan yang jelas. (4) Dokumen berupa nama siswa (5) metode tes digunakan untuk memperoleh data tentang motivasi siwa sebelum penelitian, selama penelitian dan setelah penelitian. Analisis data dilaksanakan sejak tindakan pembelajaran dilakukan selama proses refleksi sampai selesai.

\section{HASIL DAN PEMBAHASAN}

Penyusunan perencanaan pembelajaran Aqidah Akhlak pokok bahasan menghindari Akhlak tercela kelas VIII 1 MTs Negeri 1 Baubau Sulawesi Tenggara semester genap tahun pelajaran 2019/2020 dengan mengunakan metode pembelajaran cooperative script terlihat meningkat dari siklus ke siklus. Hal ini dapat dilihat dari dari hasil observasi pada siklus I mencapai nilai rata-rata 90,65 siklus II mencapai nilai 90,69 dan siklus III mencapai nilai 91,23. Hal ini menunjukkan bahwa guru mengalami peningkatan kemampuan dalam penyusunan perencanaan pembelajaran. Sehingga dengan demikian dapat disimpulkan bahwa dengan menggunakan metode pembelajaran $l$ pada mata pelajaran Aqidah Akhlak pokok bahasan menghindari akhlak tercela di kelas VIII 1 MTs Negeri 1 Baubau Sulawesi Tenggara semester genap tahun pelajaran 2019/2020 terbukti dapat meningkatkan kemampuan guru dalam penyusunan perencanaan pembelajaran.

Pelaksanaan pembelajaran Aqidah Akhlak pokok bahasan menghindari akhlak tercela di kelas VIII 1 MTs Negeri 1 Baubau Sulawesi Tenggara semester genap tahun pelajaran 2019/2020 dengan menggunakan metode pembelajaran cooperative script yang dilakukan oleh guru telah menunjukkan kegiatan pembelajaran yang mengacu kepada diskusi aktif, inovatif, kreatif, efektif, dan menyenangkan. Kemampuan guru dalam melaksanakan pembelajaran terlihat meningkat dari siklus kesiklus. Hal ini dapat dilihat dari hasil observasi pada siklus I mencapai nilai rata-rata 89,81 siklus II mencapai nilai 90,22 dan siklus III mencapai nilai 91,16. Sehingga dengan demikian dapat disimpulkan bahwa dengan menggunakan metode pembelajaran cooperative script pada mata pelajaran Aqidah Akhlak pokok bahasan Menghindari Akhlak Tercela di kelas VIII 1 MTs Negeri 1 Baubau Sulawesi Tenggara semester genap tahun pelajaran 2019/2020 terbukti dapat meningkatkan kemampuan guru dalam melaksanakan pembelajaran.

Prestasi belajar Siswa kelas VIII 1 MTs Negeri 1 Baubau Sulawesi Tenggara semester genap tahun pelajaran 2019/2020 setelah mengikuti pembelajaran Aqidah Akhlak pokok bahasan Menghindari Akhlak Tercela dengan menggunakan metode pembelajaran cooperative script mengalami peningkatan. Hal ini dapat dilihat dari hasil siklus I dengan nilai rata-rata 81,6 dengan persentase ketuntasan $72 \%$ pada perhitungan 7 orang yang belum tuntas dan 19 orang yang sudah tuntas dari nilai KKM yang telah ditentukan, siklus II dengan nilai rata-rata 96 dengan persentase ketuntasan $96 \%$ pada perhitungan 2 orang yang belum tuntas dan 24 orang yang sudah tuntas dari nilai KKM yang telah ditentukan, dan siklus III dengan nilai rata-rata 96,8 dengan persentase ketuntasan $100 \%$ pada perhitungan semua Siswa sudah tuntas dari nilai KKM yang telah ditentukan. 


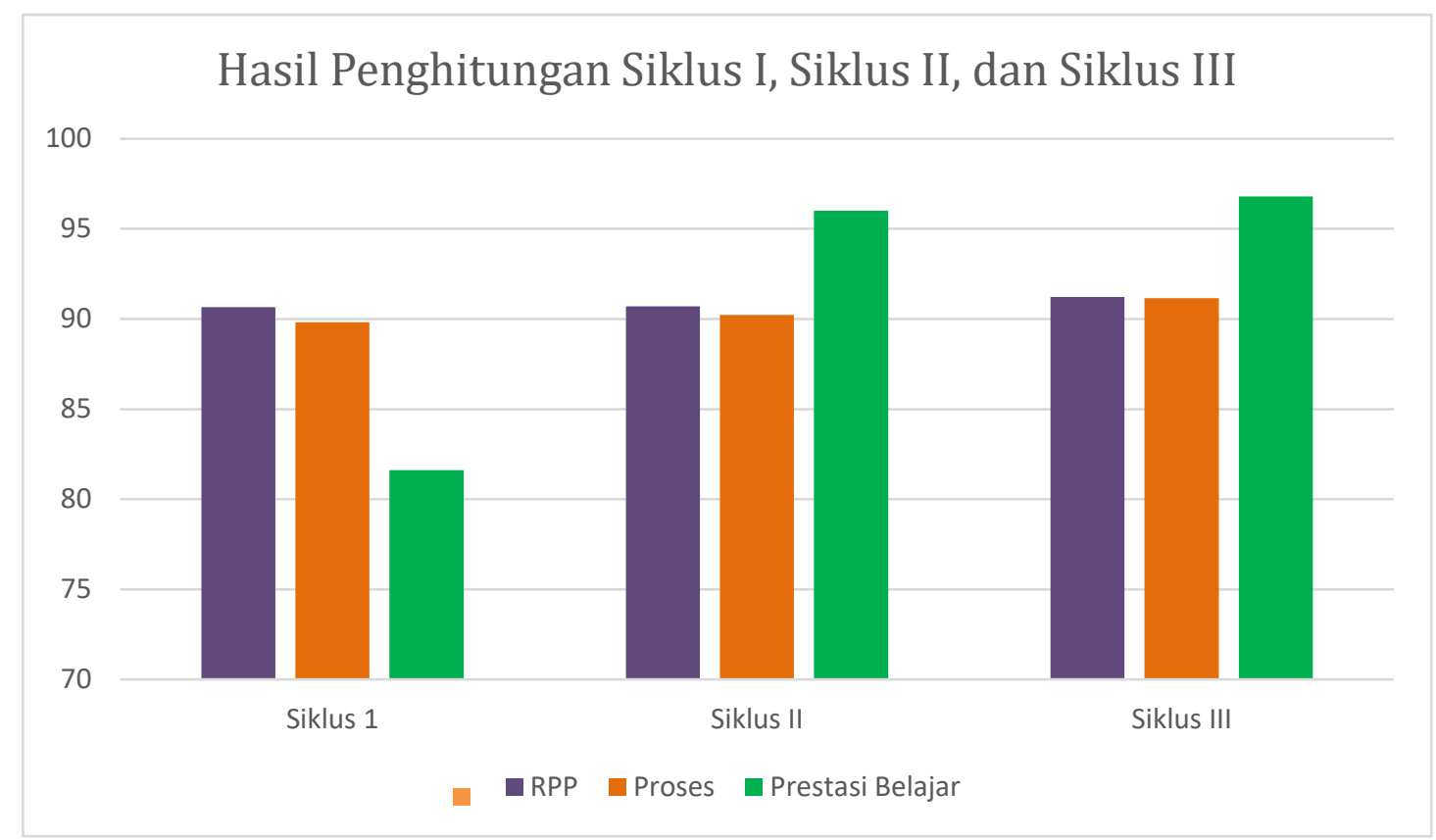

Gambar 1. Hasil Penghitungan Siklus I, Siklus II, dan Siklus III

Hasil penelitian tersebut membuktikan validitas sejumlah teori tentang cooperative script. Menurut W. Gulo Metode cooperative script merupakan penggabungan antara metode ceramah, tanya jawab, penugasan dan yang lainnya, penggunaannya harus didukung dengan alat dan media atau dengan metode lainnya yang dapat menciptakan interaksi belajarmengajar yang dinamis dan bervariasi (Gulo, 2002: 29-30).

Menurut W. Gulo disebut cooperative script karena dalam strategi ini terdapat beberapa komponen yaitu; 1) variasi metode ceramah; 2) variasi media alat indera; 3) variasi penampilan; 4) variasi bahan sajian. Adapun kelebihan dan kekurangan metode cooperative script menurut Hisyam Zaini sebagai berikut. Kelebihan metode cooperative script; 1) praktis dari sisi persiapan dan media yang digunakan; 2) efisiensi dari sisi waktu dan biaya; 3) dapat menyampaikan materi yang banyak; 4) mendorong guru atau dosen menguasai materi; 5) lebih mudah mengontrol kelas; 6) siswa tidak perlu persiapan; 7) siswa dapat langsung menerima ilmu pengetahuan. Sedangkan kekurangan metode pembelajaran cooperative script yaitu sebagai berikut; 1) membosankan; 2) informasi hanya satu arah; 3) menggurui dan melelahkan; 4) kurang terkendali baik waktu maupun materi (Hisyam, dkk, 2008). Mengikuti langkah-langkah pembelajaran metode cooperative script, penelitian ini membuktikan kesahihan langkah-langkah penggunaan metode cooperative script, yang terdiri atas: Pertama, pendahuluan atau apersepsi; kedua, penjelasan atau menyajikan materi. Langkah penyajian adalah langkah penyampaian materi pelajaran sesuai dengan persiapan yang telah dilakukan. Yang harus dipikirkan guru dalam penyajian ini adalah bagaimana agar materi pelajaran dapat dengan mudah ditangkap dan dipahami oleh siswa. Karena itu ada beberapa hal yang harus diperhatikan dalam pelaksanaan langkah ini, yaitu sebagai berikut; a) penggunaan bahasa; b) intonasi suara; c) menjaga kontak mata dengan siswa; d) menggunakan variasi yang menyenangkan.

Prestasi belajar adalah kemampuan yang diperoleh anak setelah melalui kegiatan belajar. Belajar itu sendiri merupakan suatu proses dari seseorang yang berusaha untuk memperoleh suatu bentuk perubahan perilaku yang relatif menetap. Dalam kegiatan pembelajaran atau kegiatan intruksional, biasanya guru menetapkan tujuan belajar. Siswa yang berhasil dalam belajar adalah yang berhasil mencapai tujuan-tujuan pembelajaran atau tujuan intruksional (Jihad \& Haris, 2013: 14).

Menurut Benjamin S. Bloom dalam (Winkel, 1987: 149) tiga ranah (domain) hasil belajar, yaitu kognitif, afektif dan psikomotorik. Sementara menurut A.J. Romizowski seperti 
dikutip Jihad dan Haris, hasil belajar merupakan keluaran (outputs) dari suatu sistem pemrosesan masukan (input). Masukan dari sistem tersebut berupa bermacam-macam informasi sedangkan keluarannya adalah perbuatan atau kinerja (performance). Dapat disimpulkan bahwa prestasi belajar merupakan pencapaian bentuk perubahan perilaku yang cenderung menetap meliputi ranah kognitif, afektif dan psikomotorik. Perubahan tersebut terjadi setelah proses belajar yang dilakukan dalam waktu tertentu. Benjamin S. Bloom dalam (Jihad \& Haris, 2013:14-15) berpendapat bahwa prestasi belajar dapat dikelompokkan ke dalam dua macam yaitu pengetahuan dan keterampilan. Pengetahuan terdiri dari empat kategori, yaitu: 1) Pengetahuan tentang fakta, 2) Pengetahuan tentang prosedural, 3) Pengetahuan tentang konsep, 4) Pengetahuan tentang prinsip. Keterampilan juga terdiri dari empat kategori, yaitu: 1) Keterampilan untuk berpikir atau keterampilan kognitif, 2) Keterampilan untuk bertindak atau keterampilan motorik, 3) Keterampilan bereaksi atau bersikap, 4) Keterampilan berinteraksi.

Untuk memperoleh prestasi belajar, dilakukan evaluasi atau penilaian yang merupakan tindak lanjut atau cara untuk mengukur tingkat penguasaan Siswa. Kemajuan prestasi belajar siswa tidak saja diukur dari tingkat penguasaan ilmu pengetahuan tetapi juga sikap dan keterampilan. Dengan demikian penilaian prestasi belajar Siswa mencakup segala hal yang dipelajari di sekolah, baik itu menyangkut pengetahuan, sikap, dan keterampilan. Adapun penilaian dalam proses pembelajaran meliputi: 1) evaluasi formatif, 2) evaluasi sumatif, 3) pelaporan hasil penilaian, 4) pelaksanaan program perbaikan atau pengayaan (Suryosubroto, 2002: 53).

Berdasarkan pendapat di atas dapat dijelaskan sebagai berikut: 1) evaluasi formatif adalah penilaian yang dilakukan guru setelah satu pokok bahasan selesai dipelajari oleh Siswa. Penilaian formatif disebutkan dengan istilah penilaian pada akhir satu pelajaran. Penilaian ini berfungsi untuk mengetahui sejauh mana ketercapaian tujuan intruksional khusus yang telah ditentukan dalam standar kompetensi; 2) evaluasi sumatif adalah penilaian yang diselenggarakan oleh guru setelah satu jangka waktu tertentu. Penilaian sumatif berguna untuk memperoleh informasi tentang keberhasilan belajar Siswa yang dipakai sebagai masukan utama untuk menentukan nilai lapor atau nilai akhir semester; 3) pelaporan hasil penilaian. Setelah memberikan evaluasi formatif maupun sumatif, setiap tengah semester atau akhir semester guru harus mengolah nilai akhir dan memasukan dalam buku lapor, yang merupakan laporan hasil kerja. Buku lapor berfungsi untuk laporan hasil kerja sekolah kepada orang tua atau wali murid; 4) pelaksanaan program perbaikan dan pengayaan. Apabila seorang siswa dalam ulangan (tes formatif atau tes sumatif) mencapai nilai kurang dari 6,00 atau daya serapnya kurang dari $60 \%$ maka yang bersangkutan harus mengikuti perbaikan. Tujuan ulangan perbaikan adalah agar Siswa memperoleh penguasaan yang baik terhadap tujuan pembelajaran yang harus dicapai, dengan menjelaskan materi yang sedang dipelajari atau memberikan tugas tambahan kepada Siswa yaitu mengerjakan kembali soal. Bagi Siswa yang sudah mencapai standar kompetensi, sekurang-kurangnya $60 \%$ dapat diberikan pengayaan, apabila masih ada waktu untuk satu pelajaran tertentu sebelum beralih kepada materi lain.

Kehadiran faktor-faktor psikologis dalam belajar akan memberikan andil yang cukup penting. Faktor-faktor psikologis akan senantiasa memberikan landasan dan kemudahan dalam upaya mencapai tujan belajar secara optimal. Sebaliknya, tanpa kehadiran faktor-faktor psikologis, bisa jadi memperlambat proses belajar, bahkan dapat pula menambah kesulitan dalam belajar. Faktor psikologis pada umumnya meliputi kemampuan, motivasi (motif) belajar, minat dan perhatian, sikap dan kebiasaan, bakat khusus dan kesiapan belajar, sedangkan faktor fisiologis adalah kondisi fisik Siswa itu sendiri.

Metode adalah cara yang digunakan guru untuk mengimplementasikan rencana pembelajaran yang sudah disusun dalam kegiatan nyata agar tujuan yang diinginkan tercapai secara optimal. Ini berarti metode digunakan untuk merealisasikan strategi yang telah ditetapkan sehingga dapat dikatakan bahwa metode dalam rangkaian sistem pembelajaran 
memegang peranan yang sangat penting. Hal ini sesuai dengan pendapat Sanjaya yang menyatakan bahwa keberhasilan implementasi strategi pembelajaran sangat tergantung pada cara guru menggunakan metode pembelajaran, karena suatu strategi pembelajaran hanya mungkin dapat diimplementasikan melalui penggunaan metode pembelajaran.

Metode yang dilakukan guru dapat mengakibatkan penyajian bahwa pelajaran lebih menarik perhatian Siswa, mudah diterima atau dipahami Siswa dan kelas pun menjadi lebih hidup. Dengan demikian, jelas bahwa penggunaan metode sangat mempengaruhi proses belajar mengajar di kelas sehingga dapat meningkatkan perkembangan prestasi belajar Siswa. Maka dapat disimpulkan bahwa faktor-faktor yang mempengaruhi prestasi belajar salah satunya yaitu penggunaan metode dalam pembelajaran, dengan menggunakan metode pembelajaran dapat membangkitkan keinginan dan minat yang baru, membangkitkan motivasi dan rangsangan kegiatan belajar, membawa pengaruh-pengaruh psikologis terhadap Siswa, dan akhirnya akan membuahkan prestasi belajar yang baik. Adapun faktor luar yang mempengaruhi terhadap proses dan prestasi belajar meliputi faktor lingkungan, lingkungan sosial dan lingkungan alam. Kemudian juga faktor instrumen yang meliputi bahan pengajaran termasuk kurikulum, guruatau pengajar, media dan teknik mengajar, sarana dan fasilitas belajar.

\section{KESIMPULAN}

Berdasarkan hasil penelitian yang telah dideskripsikan pada pembahasan sebelumnya, bahwa prestasi belajar Siswa pada mata pelajaran Aqidah Akhlak pada siswa kelas VIII 1 MTs Negeri 1 Baubau Provinsi Sulawesi Tenggara semester genap tahun ajaran 2019/2020, dengan berbagai upaya dan tindakan telah mengalami peningkatan dari siklus I sampai pada siklus III, untuk itu dapat diambil kesimpulan sebagai berikut: 1) perencanaan pembelajaran Aqidah Akhlak pokok bahasan 'menghindari akhlak tercela' menggunakan metode cooperative script di kelas VIII 1 MTs Negeri 1 Baubau yang dilakukan oleh guru telah sesuai dengan acuan standar Kurikulum 2013, dan mengalami peningkatan setiap siklusnya. Hal ini dapat dilihat dari hasil observasi perencanaan pembelajaran pada Siklus I mencapai nilai ratarata 90,65 (baik) sedangkan pada Siklus II mencapai nilai rata-rata 90,69 (baik) dan pada Siklus III mencapai nilai rata- rata 91,23 (sangat baik).2) Pelaksanaan pembelajaran Aqidah Akhlak pokok bahasan 'menghindari akhlak tercela' dengan menggunakan metode pembelajaran cooperative script di kelas VIII 1 MTs Negeri 1 Baubau Provinsi Sulawesi Tenggara semester genap tahun ajaran 2019/2020 yang dilakukan oleh guru telah menunjukkan kegiatan pembelajaran yang mengacu pada pembelajaran aktif, inovatif, kreatif, efektif, dan menyenangkan. Kemampuan guru dalam melaksanakan pembelajaran terus mengalami peningkatan dari siklus ke siklus. Hal tersebut dapat dilihat dari hasil observasi pada Siklus I kemampuan guru mencapai 89,81 (baik) sedangkan pada Siklus II mencapai nilai rata-rata 90,22 (baik) dan pada Siklus III mencapai nilai rata-rata 91,16 (sangat baik). 3) Prestasi belajar siswa kelas VIII 1 MTs Negeri 1 Baubau setelah mengikuti pembelajaran Aqidah Akhlak pokok bahasan 'menghindari akhlak tercela' mengalami peningkatan dari siklus ke siklus. Hal itu dapat dilihat dari nilai tes pada Siklus I mencapai nilai rata-rata 81,6 (baik) dengan persentase ketuntasan $72 \%$ sedangkan pada Siklus II mencapai nilai rata-rata 96 (baik) dengan persentase ketuntasan 96\% dan pada Siklus III mencapai nilai rata-rata 96,8 (baik) dengan persentase ketuntasan $100 \%$.

\section{DAFTAR PUSTAKA}

Gulo, W. (2002). Strategi Belajar Mengajar. Jakarta: PT. Grasindo.

Hodijah, S. (2016). Pengaruh Kedisiplinan Guru Terhadap Kedisiplinan Belajar Siswa Pada Mata Pelajaran Aqidah Akhlak Di SMP Ma'had Islam Semarang (Doctoral dissertation, Fakultas Agama Islam UNISSULA).

Hisyam, Z., \& dkk. (2008). Strategi Pembelajaran Aktif. Yogyakarta: Pustaka Insan Madani. Jihad, A., \& Haris, A. (2013). Evaluasi Pembelajaran. Yogyakarta: Multi Pressindo. 
Mufarokah, A. (2009). Strategi Belajar Mengajar. Yogyakarta: Teras.

Muqorrobin, M. N. (2017). Pendekatan Guru Aqidah Akhlak Dalam Meningkatkan Akhlakhul Karimah Siswa di MTS Al-Ghozali Panjerejo Rejotangan Tulungagung. Skripsi.

Natalina, M. (2013). Penerapan Model Pembelajaran Cooperative Script Untuk Meningkatkan Aktivitas Dan Hasil Belajar Biologi Siswa Kelas VII5 SMP Negeri 14 Pekanbaru Tahun Ajaran 2012/2013. Biogenesis, 10(1), 44-52.

Noor, A. J., \& Norlaila, N. (2014). Kemampuan Pemecahan masalah matematika siswa dalam pembelajaran matematika menggunakan model cooperative script. EDU-MAT: Jurnal Pendidikan Matematika, 2(2).

Nurhayati, N. (2014). Akhlak dan Hubungannya Dengan Aqidah Dalam Islam. Jurnal MUDARRISUNA: Media Kajian Pendidikan Agama Islam, 4(2), 289-309.

Pamuji, A. I. (2018). Problematika Pembelajaran Pendidikan Agama Islam Mata Pelajaran Aqidah Akhlak Pada Siswa Kelas VII SMP Muhammadiyah 1 Purwokerto Tahun 2017/2018 (Doctoral dissertation, Universitas Muhammadiyah Purwokerto).

Shoimin, Aris. (2014). Model Pembelajaran Inovatif dalam Kurikulum 2013. Yogyakarta: ArRuzz Metode.

Slavin, R. E. (2011). Psikologi pendidikan teori dan praktik. Jakarta: indeks.

Sudjana, N. (2004). Dasar-dasar Proses Belajar Mengajar. Bandung: Sinar Baru.

Suryani, N. K., Atmadja, N. B., \& Natajaya, I. N. (2013). Pengaruh model pembelajaran cooperative script terhadap hasil belajar sosiologi ditinjau dari motivasi berprestasi siswa kelas X SMA PGRI 1 Amlapura. Jurnal Administrasi Pendidikan Indonesia, 4(1).

Suryosubroto. (2002). Proses Belajar Mengajar di Sekolah. Jakarta: Rineka Cipta.

Syah, Muhibbin. (2013). Psikologi Belajar. Jakarta: Rajawali Press.

Widyawati, A., \& Prodjosantoso, A. K. (2015). Pengembangan media komik IPA untuk meningkatkan motivasi belajar dan karakter siswa SMP. Jurnal Inovasi Pendidikan IPA, 1(1), 24-35.

Winkel, W. S. (1987). Psikologi Pengajaran. Jakarta: Gramedia.

ZAMIL, U. (2017). Upaya Peningkatan Hasil Belajar Siswa Pada Mata Pelajaran Aqidah Akhlak Materi Ajar Iman Kepada Rasul Melalui Penerapan Metode Kooperatif Learning Model Make A Match (PTK di Kelas VIII MTs. Al-Hikmah Curug Kab. Tangerang) (Doctoral dissertation, Universitas Islam Negeri" Sultan Maulana Hasanuddin" BANTEN).

Zamzani, R., \& Munoto. (2013). Pengaruh Teknik Pembelajaran Cooperative Script Terhadap Hasil Belajar Siswa Pada Mata Diklat Menerapkan Dasar-Dasar Elektronika pada Siswa Kelas X TAV Di SMK Negeri 1 Sidoarjo. Jurnal Pendidikan Teknik Elektro, 343-350. 